\title{
Internationalization of Service Firms and Their Interactions with Socio-Political Actors
}

\author{
Agnieszka Chidlow ${ }^{1} \cdot$ Pervez N. Ghauri $^{1} \cdot$ Amjad Hadjikhani $^{2}$
}

Published online: 10 July 2019

(c) Springer-Verlag GmbH Germany, part of Springer Nature 2019

\begin{abstract}
Although there is extensive research in the field of services and lately on the internationalization of services, the topic of how service firms interact with society and political organizations, during their internationalization process, remains almost untouched. As an answer to the call for further research on the interaction between service firms, society and policy makers, this paper aims to advance the knowledge by proposing an integrative theoretical view. Dissimilar to the earlier research where each study stands on a specific theoretical discipline (economic, behavioural or political science), the proposed theoretical view asserts the need for an interdisciplinary approach. The integration of these three perspectives is vital since business, policy and society have different legitimacy and dependency grounds and yet their goals and objectives have been converging over the years. Isolating these disciplines from each other is, thus, not very helpful in advancing the knowledge and understanding the conditions, motives and consequences of multinational enterprises in foreign markets. Moreover, the internationalization of services and the extent of heterogeneity in service products/solutions, from banking to retailing and e-commerce, create new challenges that need for interaction between these parties; the three pillars of our society.
\end{abstract}

Keywords Internationalisation - Service firms · Socio-political actors · Interdisciplinary approach $\cdot$ Society and politics

Agnieszka Chidlow

a.chidlow@bham.ac.uk

1 Department of Strategy and International Business, The University of Birmingham, Birmingham Business School, Birmingham, UK

2 Department of Business Studies, Uppsala University, Ekonomikum, Uppsala, Sweden 


\section{Settings the Research Arena}

The interplay between society and political organization in the internationalization process of multinational enterprises (MNEs) has become a crucial issue in international business (IB) research (Shirodkar et al. 2018). While there has been extensive research on internationalization of industrial firms (Clark and Rajaratnam 1999; Zaefarian et al. 2015) and recently on the role of political and social organizations (Ghauri et al. 2015), there are shortcomings on studies that cover the internationalization of service firms interfacing social and political organizations (Hadjikhani et al. 2016; Wickert 2016). Regarding industrial firms there has been some attention to research on interaction between MNEs, society and political (Hadjikhani et al. 2001, 2012) and in the field of Corporate Social Responsibility (CSR) which is elaborated since 1930s (Berle and Means 1932; Ghauri et al. 2015; Okoye 2009). However, even in the field of industrial MNEs it is only recently that firms have realized the unavoidable influence of socio-political actors on their legitimate market position (Ghauri et al. 2012). Whether it is industrial firms or service firms, researchers like Polonsky and Jevons (2009), Ghauri et al. (2012) and Marquina and Morales (2012) have a consensus and explain that management of social and political environments is the key for marketing strategy and that it influences competition, market image and success in entry and expansion in foreign markets. Despite the increasing number of Service Multinational Enterprises (SMNEs), there are significant shortcomings as to how these firms interact with socio-political units. A further research is therefore, required (Ghauri et al. 2012; Oh et al. 2013). Moreover, it is crucial to understand international strategies and activities of SMNEs due to an increasing proportion of services in international trade and investments in the extensive globalization of services.

We hope this paper will contribute toward new knowledge and encourage researchers to embark on further research using interdisciplinary approaches to examine SMNEs. In line with these thoughts, this paper will first discuss the setting of this tradition and then elaborate how an integrative view among these three fields (business, policy and society) contribute new knowledge and how they are connected.

\section{Boundary Setting of the Field}

The topics under concern of this research hold the three research fields of; SMNEs, political units and society as depicted in Fig. 1. Each of these fields has attracted several researchers but with different theoretical grounds and empirical settings. A brief research on the number of articles connected to these topics covering more than 3 decades discloses interesting facts. For example, in the search of the articles in EBSCO host (2018-06, A and B) dealing with MNEs and their interaction with political actors, studies on SMNEs are much less than on manufacturing firms (i.e., 33,765 for manufacturing firms and articles dealing with the 
Fig. 1 The three pillars: firms, policy makers and society. SMNE service multinational enterprises, $P$ policy makers, $S$ society

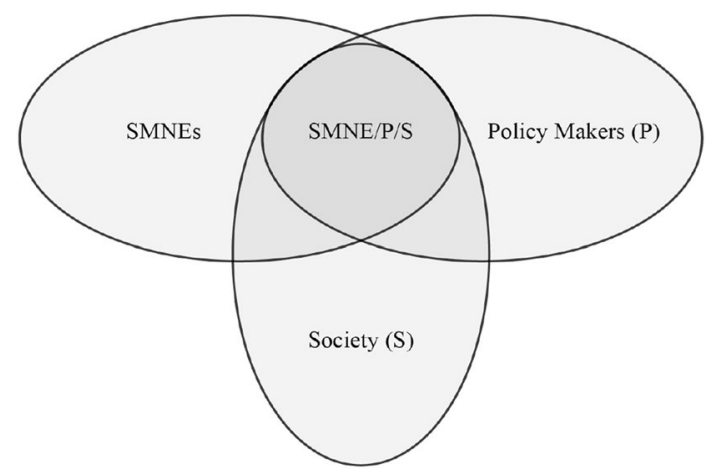

interaction between SMNEs, socio and political actors are 879). The search for articles in the internet library, EBSCO, business source complete, (2018-06, B) also indicates that the studies on SMNEs covers different fields like consulting firms, hotels, banks and knowledge firms. While the combination of topics like international service firms and political organizations hits 879 , the combination of SMNE, society and policy become much less, 128 (2018-06, C). This search demonstrates the lack of research in the field of SMNEs connected to socio-political units.

Although, there are few studies that reveal the interesting issues concerning the varieties in the theoretical grounds and the empirical settings. Recently several researchers have introduced views on the interaction between the firms, and sociopolitical actors and the complexity of this relationship (Hadjikhani et al. 2016). They pinpoint that SMNEs can improve their market position by taking appropriate managerial actions towards socio-political organizations. In fact, this provokes research to understand the interaction between service firms and socio-political organizations in both local and foreign markets.

\section{Internationalization of Service Firms}

The role of service firms in the economy and society has captured the attention of recent studies. These studies show, that the service sector in USA accounts for $80 \%$ of GDP and private and non-farm employment (Clark and Rajaratnam 1999; Hadjikhani et al. 2016; Ross and Crossan 2012). However, despite the increasing proportion of services, there is a dearth of research in this field. During the last 4 decades the number of articles is about $0.4 \%$ of the total published papers in the management field (EBSCO 2018).

The changing landscape of IB, globalization and a further internationalization of services pose new challenges. Moreover, the heterogeneous nature of the type of services from banking to retailing, has led to questions that whether existing theories based on internationalization of manufacturing firms can equally explain the internationalization of services firms or not? As stated by Clark and Rajaratnam $(1996,1999)$ what these theories have in common is the implicit concern as 
to how and why services cross national boundaries. In such theories, modes of entering foreign markets are vital for clear understanding of services. In line with these thoughts an inspection of previous classification schemes reveal four idealized types:

1. Contract-based services represent firms, for example, consultancy services where consumers and producers from different countries come close for transactions.

2. Vehicle-based services in this type of firms' communications between domestic and international market is directed through, vehicles such as satellites and wires or TV.

3. Asset-based services, this type of firms require platforms, such as banks, where services cross borders with FDI.

4. Object-based services manifest integrated services with physical objects (like DVD, information/manuals for machinery services etc.).

Given the diversity the services and mode of delivery, Richardson (1987) states that no single theory is probably suitable. However, the above classifications scheme may serve as a starting point for employment of a variety of theories. Authors like Clark and Rajaratnam (1999) connect the selection to the types and the nature of services. In other words, the classification schemes become related to the degree of (a) intangibility, (b) heterogeneity, (c) perishability and (d) inseparability. While the first characteristic (contract-based) is the purest type, as it exhibits the classic nature of services, the other types manifesting this with varying degrees. These types also manifest the varieties of connections with political units and society. Vehicle-based services, for example, allow producers to be present without actually crossing the borders. Although, the governments try to exercise some control over, for example, communication transmitted across their boundaries (Chandran and Pandiyan 1987; Ross and Crossan 2012). A service is thus internationalized when it operates in foreign country using any of the above classifications. These classifications also determine how the services become interconnected to business, society and political issues in foreign countries. Comparatively, internationalization of products follows the same path, however, services are both varied and complex and/or move easier and faster (Yuliani and Ashly 2017).

Quite different to this line of thought and similar to the studies in manufacturing firms some authors uncover that SMNEs' behavior is (a) customer following, (b) follow the leader or (c) market seeker (Cardone-Riportella et al. 2003). Lovelock and Yip (1996) classify services into three groups depending on society involvement: (a) people-processing, involving tangible services like restaurant and healthcare which requires presence in the foreign market, (b) possessionprocessing that holds intangible actions like transportation, appliance repair in which the customer is not involved in the process, and (c) information-based in which the service firms provide a value for the customer (like collection of data, analysis, accounting, and insurance) which may or may not involve customers in the foreign market. Beside the degree of society involvement, the classifications 
manifest the degree of intangibility and the heterogeneities in the types of service firms. This classification is sometimes also explained to be related to if the service firms are capital-intensive or knowledge intensive (Abdelzaher 2012).

Challenging the nature of heterogeneity in SMNEs' choice of foreign commitment mode authors like Blomstermo et al. (2006) and Grönros (1999) divide the services into hard and soft. The distinction is connected to the service production and consumption which in soft category occurs almost simultaneously. Soft group is viewed as internationalizing via contractual entry modes like licensing and franchising. In contrast, the hard service, the consumption and production are decoupled (Blomstermo et al. 2006). Because of this nature, scholars found similarities between hard service and manufacturing firms and large difference between soft service and manufacturing firms' internationalization.

\section{SMNEs and Political Connections}

There seem to be an extensive research on the role of government in banking industry (Kizys et al. 2016; Ting 2017) and hotel industry (Auliandri and Angraeny 2017; Wang and Chaudhry 2018). However, the attention of researcher on the topic of connection between SMNEs and political units appears to be rather limited (Hadjikhani et al. 2014) as it is only during the last 3 decades that studies have initiated new thoughts on theorizing this relationship (Rjavalgi and Grossman 2014; Ross and Crossan 2012).

One crucial aspect raised in the thoughts of researchers in SMNEs is the specificity in the firms' political actions which can also be traced in the studies of manufacturing firms. In the research track of corporate governance in both studies of service and manufacturing the main standpoint is specificity and heterogeneity in the impact of the governmental decisions on business firms and the firms' unique strategy towards governance (Ross and Crossan 2012). Some researchers, such as Nomden et al. (2003), implicitly stand for institutional theory. Others, such as Crystal (2003), specifically relate the firms' resources and strategy towards host government (Hadjikhani et al. 2016). In their conceptual development some propose resource-based theory and stress the specificity in the firms' resources and their relationship with host governments.

Though, after the financial crises of 2008/2009 a large number of studies have emerged in economics and business fields concerning the impact of the crisis on SMNEs like banks and business firms (Engwall and Hadjikhani 2014; Howcroft et al. 2010; Khaaoubi 2007). Linking economic crises and the role of the governments to the international business bank service crises, some stipulate the interdependency of MNEs to the government regulations in different countries (Mendoza and Smith 2014), and their impact on productivity and welfare (Benigno and Fornaro 2014). Others like Bruno and Shin (2014) study the rule of monetary and regulatory policy in international financial systems in an integrated business world. In this connection, studies like Howcroft et al. (2010) and Arena (2008) relate the crises to external issues like government intervention or Ross and Crossan (2012) and Laeven 
and Levine (2009) that explicitly explain the lack of interaction between financial systems and governments.

The ground for the role of governments, as stated by Hadjikhani and Ghauri (2001) is that there exists interdependency between governments and MNEs for reasons like local employment and GNP. In internationalization of services such interdependency is embodied with a highly heterogeneous nature from the extensive variety in service products. Some service products can remain elusive and largely invisible in foreign markets and some that are more visible (Samee 1999). Some SMNEs surge local employment and some generates no employment. When controlling SMNEs there are limited information available for how governments handle such diversity of the service products. For governments aiming at exercising political rules on SMNEs, for example, concerning international trade and marketing of service products, the task remains complex and not well understood. This explains the lack of fundamental knowledge that restricts governments and managers in negotiations for the advancement of welfare for the society.

\section{SMNEs and Socio-Political Actors}

The interplay between socio-political organizations and MNEs has become a crucial issue in IB studies (Crane and Desmond 2002; Hadjikhani et al. 2001; Rjavalgi and Grossman 2014; Keillor and Hult 2004) in order to explain MNEs market positions not just due to their actions in the business arena but also due to their ability to manage the socio-political units in foreign markets. In this research field, the number of studies employing economic theories is increasing as the hierarchical role of governments exercising their power through, for example, tax increase and cuts in public services have attracted a number of researchers (Nederhand et al. 2016). Research based on behavioural theory is however less "comfortable" in the use of systematic theoretical tools for further understanding of SMNEs' socio-political environment. According to Simonin (1997) and Hadjikhani et al. (2001), firms undertake investment decisions towards society to gain support for their business, and society becomes dependent on MNEs because of their investments in employment and welfare.

\section{Towards a Theoretical Proposition}

Despite the lack of significant contributions, the overview of the earlier research helps to ground a theoretical proposition to examine the three pillars in internationalization of services discussed above. This is because no matter if the studies main concern is not directly related to SMNEs and socio-political actors but they reveal the existence of (a) heterogeneity in the service products, (b) heterogeneity in the internationalization mode and firms' behavior, and (c) diversified needs and actions of social and political units. For the assumption of a need for a theoretical framework that enables the integration of views and concepts from different disciplines, the fundamental ground in this proposition relies on four conceptual elements; 
1. Heterogeneity in the firms' resources,

2. Heterogeneous political needs and actions,

3. Society's demands, values and actions.

4. For the connection between these three pillars the proposition relies on the concepts of uncertainty, legitimacy and trust (Fig. 2).

For the first concept, the effort deploys the view of connection between SMNEs' resources and the internationalization. An interesting issue in this respect is that while some service firms with soft nature need low capital investment for their presence in foreign markets, other service firms, like asset-based firms need large investment (Blomstermo et al. 2006; Clark and Rajaratnam 1999).

For the heterogeneous nature of service internationalization mode, firms thus can be present in several foreign markets with no or low capital investment. Though, facing low capital risk and uncertainty. Some scholars point out the vital characteristics, such as; intangibility, inseparability, heterogeneity, perishability and ownership that extricate the service industry from other industries. These characteristics effect on the range of factors including competitiveness and geographical distribution (Ghauri et al. 2012). These authors further demand a need for models going beyond the traditional theories since service firms' are highly heterogeneous and interact with environment differently.

While political actors, such as government, stress the repeated procurement setting and homogeneous implementation of their decisions, MNEs aim to gain heterogeneity in these gains and impacts. MNEs' investment in the social and political market is to have a specific relationship and gain specific support, which strengthens their competitive position. Such a view relies on a relationship explanation between SMNEs and socio-political actors. This is because firms are dependent on sociopolitical units as they can support SMNEs or act against them (Delios and Henisz 2003), and can generate either trust or distrust between SMNEs, society and political units. At the same time, socio-political units are dependent on MNEs because they have resources and commit investments that, in turn, affect groups like the

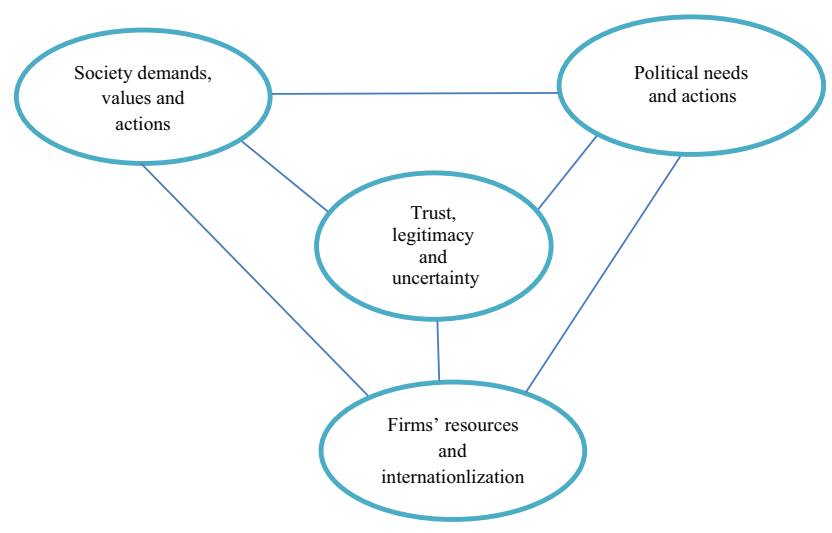

Fig. 2 A theoretical proposition 
media and the public at large, on which the social and political units are dependent (Figueira-de-Lemos and Hadjikhani 2014; Hadjikhani et al. 2016). Based on this need for interaction, researchers call for the explanation that how the actors in three pillars are interdependent.

In line with interdependency, Arena (2008) relates the stability and critical conditions in service firms to external issues, while Connelly (2007) connects them to the risk taking or mismatch of service firms and their social and political environments (Laeven and Levine 2009). The undisclosed side of these strategies is the connection between internationalization and managing both stable and critical conditions in foreign service markets (Dikova et al. 2013; Engwall and Hadjikhani 2014). While some scholars concern the interdependency of financial systems in different countries and their impacts on productivity and welfare (Benigno and Fornaro 2014; Mendoza and Smith 2014), others study hierarchical power of government and the rule of regulatory policy in an integrated business world (Bruno and Shin 2014).

Seemingly and despite a high level of heterogeneity in service products, the earlier SMNE studies have been following the same drift as industrial firms' internationalization. For the first set, the factors explaining foreign market choice is grouped into the levels of host country and firms' resources, and finally the differences between the home and the host country's social values and needs (Nielsen et al. 2017; Voss et al. 2010). While the first factor is connected to economic and transaction cost theory the two others are connected to resource based and institutional theory. Zhou et al. (2009) suggest that the high heterogeneity in services however, moderates the relationships between, for example, transaction costs and internationalization mode.

The proposition in the effort stands close to Schwarz and Schuman (1997) and Pla-Barber et al. (2014) statement that these two characteristics that have been recognized as moderators are the level of capital intensity and the degree of customization. For the service products the level of capital intensity largely varies among different services. This is because the object or people-based service firms, like international consulting and legal services, demand high resource commitments and are similar to wholly owned subsidiaries (Clark and Rajaratnam 1996). But resource commitment is intangible and people intensive, requiring low expenses. Also, entry and expansion with low capital relies on trust and reputation. Some service firms can easily move from one market to another but can also loose trust towards society and political units. Society distrust is embodied with high uncertainty even in foreign service modes that local investment is absence. In this internationalization mode the crucial commitment of the firms is to develop trust. On contrary, internationalization in the hotel industry requires high capital intensity and high tangible commitment (Litteljohn et al. 2007).

The fundamental differences between players in three pillars intricate the view of trust and legitimacy. These players belong to different systems and have heterogeneous legitimacy perceptions (Mobus 2005) grounded in institutional theory. While international service firms have business legitimacy, society has its legitimacy on economic demands and social values. SMNEs are interdependent with the political units as they can gain support/exertion affecting their interaction with local market and subsequently their competitive position in the market. 
Some relations with political units have a generalized exchange while others have a specific exchange in which the reciprocity is not necessarily achieved through any direct benefit to one actor over another, as it may be achieved through an indirect benefit. Political units' relation with SMNEs can indirectly fulfil the demands of the society. The vital question can be how the firm's entry mode of internationalization affects the society. Thus, the political units' action towards service firms' internationalization modes is vital for firms' commitment decisions in a foreign market. Nonetheless, the view installs the degree of political actions towards SMNEs which can be (a) generalised action and (b) specific action. While the general action concerns political rules concerning all the service firms or all foreign firms in a service industry, the specific dimension is explicit and directed towards a specific international service firm. These actions are presumed to be undertaken by governments towards firms in their internationalisation efforts. Simply, it can be stated that the political units are composed of at least three different and heterogeneous units working with varieties of actions and expecting different outcomes.

While contract-based services mainly concern bureaucrats, the asset-based involves both government and bureaucrats. The main concern of government and members of the parliament is to understand and follow the demands and values in the society. The needs of the society can simply be divided into two categories such as (a) individual demands, needs and action and (b) general needs and values.

The individual needs are related to the issues like employment, welfare, income and security. The general needs refer to the preservation of social and cultural values as well as transparency in the behavior of the players. Decision of government and parliament towards foreign firms are ultimately scrutinized by the society and individual groups. Their decisions, if they are trustful or not can vary from support or silence to strikes and violence. Final manifestation of trust/distrust is their votes in election. The political groups for their legitimacy are to show their legitimate power towards the foreign firms. Foreign services following, and satisfying individual and society demands will strength their position towards the society and political units (government and parliament). The complexity in these interactions entails employment of views from different theoretical grounds. While trust is a behavioral theory, hierarchical power is based on economic theory and legitimacy is derived from institutional theory.

The study of Clark and Rajaratnam (1999) inspires the idea of connection between the theoretical selection and the internationalization types; related to contract based, vehicle based, asset based or object based services. In their deeper proclamation they explain the heterogeneities in the impact of social factors (culture) and political factor on service firms. Intangibility of a resource commitment in the contract based services (people crossing the boarders), create problems for governments as these services cannot be detected or controlled.

According to Dahringer (1991) the fundamental problem is largely due to the close cultural relationships between the society and some types of service. Differences in language and in national culture have similar effect as customs duties. For the lack of tangibility in some service products the extent of burden of service adaptation to the local social and cultural values escalates. Moreover, customization in service products contains learning process between firms and its customers which 
requires a high degree of indirect contact and/or direct personal contact for judgment and adaptation during the delivery of the services. However, some researchers state that the process of internationalization in manufacturing firms is slower than service firms (Gabrielsson et al. 2014) which confronts the firms with not only differences in capital intensity but also the intensity and time aspects on the impact of political and social environments.

For exploring the political actions, the effort stands on the interdependency view but also the view that sometimes firms are to obey the political rules in the foreign markets. This denotes to include views on political hierarchy from economic science. Thus, the proposed view stands on both hierarchical power of political units in economic science and the relationship view in behavioral science. In line with this there are some recent studies that divide the political actions into two types, coercive and supportive (Ghauri et al. 2012). Some other studies have developed ideas that the major problem in, for example, financial crises, has been the neutral position of the governments to control the service market (Hofmann et al. 2014). The discussion reveals another interesting issue that the political behaviour of government, beside the dimension of general and specific dimensions, holds also another dimension. In this dimension the political behaviour of the government can be divided into (a) coercive, (b) supportive, (c) unable to control and (d) neutral position.

Whereas the first two alternative actions can simply be exercised for firms in financial services, the third one concerns internationalization modes like digital services sometimes out of governmental power. The exercise in the latter is in the range of society constructed on trust to the firms' legitimate behavior. While the specific coercive political action towards SMNEs sometimes derives the firms to reduce capital investment or exit, the specific supportive actions motivate for entry and expansion (Figueira-de-Lemos and Hadjikhani 2014). For the size of tangible capital investment while the exit strategy is simpler for a number of service firms compared with industrial firms which is more problematic. Since the size of intangible commitment for SMNEs are high, for example in building trust, the adaptive strategy of the firms can be reached easier. The main strategy of the firms is thus to convert the specific coercive actions to specific supportive one. Thus, beside the adaptive strategy like exit, firms can undertake the influential action through relationship or business power to change the behavior of political unit. Accordingly, as Katsikeas and Theodosiou (2006) stipulate the actions of international service firms can be either adaptive or influential.

Contrary to relationship view, adaptive behaviour relies on hierarchical power of the government grounded on political hierarchy in economic science. Adaptive firms can hold a number of strategies. While some services hold the strategy of organizational change or just clicking on a bottom (in some IT services) others relies on structural change varying from simple adaptation to more radical changes. In conditions where the government are facing distrust from the society they are to manifest and undertake extensive coercive decision. In such a case the firms' adaptive behaviour is not sufficient and the only strategy is market exit. The study of Figueira-deLemos and Hadjikhani (2014) manifest that in cases of high turbulence in general political environment service firms can easily resort to the strategy of wait and see. When coercive behaviour of political units is general the strategy of 'wait-and-see' 
is not costly since the capital investment of service firms compared to industrial firms are not high.

The need for influential behaviour of service firms in foreign market can drastically vary. For products where internationalization is digital the level of interaction is low and needs for influential actions are also low. Unless cases with critical conditions. On contrary, service products that hold a high level of tangible capital investment impose direct interaction with political units. The influential activities are to influence the political decision for gaining specific support. As discussed, the influential firms hold a variety of strategies ranging from simple to complex opaque behaviour, such as (Ghauri et al. 2015): (a) information exchange, (b) negotiation, (c) cooperation, (d) lobbying, and finally, (e) corruption.

While the first strategy stands for legitimate action and holds to provide knowledge about the service and its benefits to the society and political units, the last exhibits illegitimate behaviour when the information reaches the society. After the pioneering study of Rose-Ackerman (1978), the rapidly growing access to knowledge has extended the attention of business, society and political units towards the question of how the information on MNEs' and political units' interaction follows the prevailing social values and legitimate rules.

Within this context, the emphasis on access to knowledge and its impact on business performance has increased considerably (Ghauri et al. 2006). As the study of Ghauri et al. (2015) expose, while transparent legitimate actions like negotiation and cooperation strengthen the firms' market position, information on illegitimate behaviour has severe negative consequences on business trust. As the above study manifests, as far as the knowledge about the service firm's corruptive behaviour was opaque and not disclosed for the society and foreign countries, the firm had success in the foreign market. The uncertainty for the future arrived when the information reached the society and other parties. The uncertainty finally enforced the firm to exit from the foreign market.

While some are in favour of availability of knowledge for society and market participants (Ghauri et al. 2006), others are against and proclaim the view as an ideal condition far from political and business realities. Lobbying behaviour which theoretically proclaims to hold availability of knowledge (Hadjikhani and Pahlberg 2014) is constructed on ability of international service firms in using the knowledge and resources to gain some control over the socio-political environment and to strengthen trust. Simply, lobbying activities are firm specific, heterogeneous and knowledge is not available for other parties. Firms choose lobbying the political environment to gain specific support that others cannot have. Mobilization of resources and knowledge is to interact with the political groups and gain benefit that strengthens their competitive position in the international market.

This line of thought has occupied researchers in the last century. Delios and Henisz (2003) and Scott (1995) discuss managerial actions, such as, lobbying and connect it to the firms' management competency. In this manner, Delios and Henisz (2003) goes further and introduces the idea of a firm's interaction with society and connects it to the behavioural action of lobbying and influence. It is stated that firms use their direct and indirect ties with political and social units to strengthen their competitiveness. In the context of managerial capability, Delios 
and Henisz (2003) introduces concepts like legitimacy, lobbying, knowledge and influence, which assist the theoretical ground of this study (Hadjikhani and Pahlberg 2014). But service internationalization modes with no or low interaction with political units the relationships is with customers and society constructed on trust.

An interesting issue concerning the governments' control of foreign firms is that service firms especially banks are subject to both high entry control and high performance control. Charters are required for the start-up of firms and when a charter has been granted, the performance of the service is scrutinized by government bodies. On contrary, there are service firms that the foreign governments do not have (a) sufficient knowledge (b) the firms can easily become international, no matter of size, and the governments do not have much control. Customers and others in the society can easily have access to products and governments have difficulty to intervene. In this extent of governmental impact, the crucial issue challenging all the three parties is trust.

A fundamental reason for the political regulations is the need to retain social trust in, for example, banking institutions that those who put their money into a bank will have their money back on request. Sudden loss of trust will, as history has shown, lead to a run on the service firms as well as government (Friedman and Schwartz 1963). This in turn will not only have implications for the service firm which is distrusted but will have repercussions in the whole system (Engwall and Johanson 1990). However, even these firms can easily leave the foreign market when the distrust is high. The loss of trust can thus be considered as a fundamental uncertainty in service, which can be labelled reputational risk. Behind this risk there are a number of other uncertainties (Voss et al. 2010).

Globalization of IT services, like face book, holds globalized trust and uncertainty. This imposes the views that trust or distrust, no matter of services requiring high or low capital investment is not a local or foreign issue. Any action of service firms diffuses rapidly and society enforces political units to act. This displays the view that while governments can undertake coercive actions towards society, society also can force government to change policy and make decisions towards service firms. The view simply has its ground in both economic and social sciences.

An explicit behaviour connecting these three actors refers to the studies in CSR. Firms' CSR activity in foreign markets is simply a strategy to influence by building trust. While there has been extensive research on CSR since the 1930s (Berle 1931; Okoye 2009), it is recently that international firms have realized the unavoidable influence of CSR and its obvious impact specifically on their legitimate position in foreign markets (Ghauri et al. 2012; Marquina and Morales 2012; Polonsky and Jevons 2009). But, implicitly manifesting the relationships between the three pillars. CSR is a mean to build and increase the trust and strengthen the legitimate position of the firms. Among the few studies researchers like Oh et al. (2013) and Hadjikhani et al. (2016) state such strategies that connect service firms to the society are deliberate behaviour for entry and expansion in foreign markets. As a consequence of extensive varieties in the service products, the political actions towards foreign service firms are highly heterogeneous. 


\section{Conclusion}

In line with the study of Ghauri et al. (2012) the proposed theoretical view on internationalisation of services, this effort not only opens new windows for development of analytical tools but also aims to stipulate the first general conclusion that a deep understanding of SMNEs internationalization and connections between the three actors requires theoretical input from a variety of scientific fields. This also discloses another general but interesting conclusion. No matter if an MNE is in service or manufacturing field, research on interaction of the firms, society and government is not indebted to be affixed in one theoretical sphere. Researchers are to have sovereignty to attach and connect concepts from different discipline as far they are compatible and permit deeper understanding of the problem under concern.

Though, it can be concluded that an analytical view is to hold conceptual elements like legitimacy, power, resources and ultimately actions which are based on different theories. The diversity encloses the presumption that business firm behaviour stands on legitimacy and trust in commitment with the absence of formal political power. Political units have political legitimacy possessing hierarchical power and resources acting in between coercive and supportive behaviour towards business firms and society. Society evaluating the legitimacy of political units within social context imposes power indirectly through votes and actions. Society interacts and claims for appreciation or avoidance behaviour towards business units. Hence, the analysis of this heterogeneity in the behaviour of these actors necessitates conceptual tools that originate from these different disciplines.

The next conclusion stands on the extent of the broader dimension of service products internationalization. Instead for generally accepted dimension of degree of intangibility, this broad dimension reflects the degree of connection to social and political units. It is to state that the internationalization modes affect the degree and level of interactions with society and political units. While some service products, like banks that are strictly regulated or international hotels where political units behave similar to the MNEs in manufacturing industries. The political actors can simply use their hierarchical power to decide and implement highly regulated rules to benefit the society. SMNEs in the digital world are in the foreign market with no investment and far from the host governments' exercise of hierarchical power. However, in cases of society distrust even these firms are to undertake several measures to rebuild trust. Beside this, governments and bureaucrats have knowledge deficiency on service markets and the role of technology that can paralyze the political units or can influence them to undertake improper decisions. It can, therefore, be concluded that the lower the political units' hierarchical power the higher the dependency of the firms on trust and legitimacy.

Based on the above, the purpose of this Focused Issue is to open new doors for both theoretical and empirical discussions in order to contribute to the further development of scholarly research regarding internationalization of service firms.

Acknowledgements We would like to thank the editors and the reviewers for their invaluable support in producing this Focused Issue. 


\section{References}

Abdelzaher, D. M. (2012). The impact of professional service firms' expansion challenges on internationalization processes and performance. The Service Industries Journal, 32(10), 1721-1738.

Arena, M. (2008). Bank failures and bank fundamentals: A comparative analysis of Latin America and East Asia. Journal of Banking \& Finance, 32(2), 299-310.

Auliandri, T. A., \& Angraeny, R. (2017). The implementation of green hotel management in Majapahit Hotel Indonesia. International Journal of Organizational Innovation, 9(3), 45-62.

Benigno, G., \& Fornaro, L. (2014). The financial resource curse. The Scandinavian Journal of Economics, $116(1), 58-86$.

Berle, A. A. (1931). Corporate powers as powers in trust. Harvard Law Rev., 44, 1049-1074.

Berle, A., \& Means, G. (1932). The modern corporation and private property. London: Macmillan.

Blomstermo, A., Sharma, D. D., \& Sallis, J. (2006). Choice of foreign entry mode in service firms. International Marketing Review, 23(2), 211-229.

Bruno, V., \& Shin, H. S. (2014). Assessing macroprudential policies: Case of South Korea. Scandinavian Journal of Economics, 116(1), 128-157.

Cardone-Riportella, C., Alvarez-Gil, M. J., \& Lado-Couiste, N. (2003). The relative effects of clientfollowing and market seeking strategies. International Journal of Management, 20(3), 384-394.

Chandran, V. G. R., \& Pandiyan, V. (1987). Technical efficiency and technological change in Malaysian service industries. Applied Economics Letters, 15(8), 655-657.

Clark, T., \& Rajaratnam, D. (1996). Towards a theory of internationalization services: Marketing insights in a world of nations. Journal of International Marketing, 4(2), 9-28.

Clark, T., \& Rajaratnam, D. (1999). International services: Perspectives at century's end. Journal of Services Marketing, 13(4-5), 298-310.

Connelly, S. (2007). Mapping sustainable development as a contested concept. Local Environment, 12(3), 259-278.

Crane, A., \& Desmond, J. (2002). Societal marketing and morality. European Journal of Marketing, $36(5-6), 548-569$.

Crystal, J. (2003). Bargaining in the negotiation over liberalization trade in services: Power, reciprocity and learning. Review International Political Economy, 10(3), 552-578.

Dahringer, L. D. (1991). Marketing services internationally: Barriers and management strategies. Journal of Services Marketing, 5(3), 5-17.

Delios, A., \& Henisz, W. J. (2003). Political hazard, experience and sequential entry strategies: The international expansion of Japanese firms, 1980-1998. Strategic Managment Journal, 24(11), 1153-1164.

Dikova, D., Smeets, R., Garretsen, H., \& Van Ees, H. (2013). Immediate responses to financial crises: A focus on US MNE subsidiaries. International Business Review, 22(1), 202-215.

Engwall, L., \& Hadjikhani, A. (2014). Internationalization of financial services in turbulent markets. International Business Review, 23(6), 1035-1039.

Engwall, L., \& Johanson, J. (1990). Banks in industrial networks. Scandinavian Journal of Management, $6(3), 231-244$.

Figueira-de-Lemos, F., \& Hadjikhani, A. I. (2014). Internationalization processes in stable and unstable market conditions: Towards a model of commitment decisions in dynamic environments. Journal of World Business, 49(3), 332-349.

Friedman, M., \& Schwartz, A. J. (1963). A monetary history of the United States, 1867-1960. Princeton: Princeton University Press.

Gabrielsson, M., Gabrielsson, P., \& Dimitratos, P. (2014). International entrepreneurial culture and growth of international new ventures. Management International Review, 54(4), 445-471.

Ghauri, P., Hadjikhani, A., \& Elg, U. (2012). The three pillars: Business, state and society: MNCs in emerging markets. In A. Hadjikhani, et al. (Eds.), Business, society and politics (pp. 3-16). Bingley: Emerald Group Publishing Limited.

Ghauri, P. N., Hadjikhani, A., \& Johanson, J. (2006). Managing opportunity development in business network. Palgrave.

Ghauri, P. N., Hadjikhani, A., \& Pahlberg, C. (2015). Multinational corporations' relationship with political actors: Transparency versus opacity. In J. Forssbaeck \& L. Oxelheim (Eds.), The Oxford handbook of economic and institutional transparency (pp. 341-358). New York: Oxford University Press. 
Grönros, C. (1999). Internationalization strategies for services. Journal of Service Marketing, 13, 290-297.

Hadjikhani, A., Elg, U., \& Ghauri, P. (2012). Business, society and politics: Multinationals in emerging markets. Bingley: Emerald Group Publishing Limited.

Hadjikhani, A., \& Ghauri, P. (2001). The behaviour of international firms in socio-political environments in the European Union. Journal of Business Research, 52(3), 263-275.

Hadjikhani, A., Hadjikhani, A. I., \& Thilenius, P. (2014). The internationalization process model: A proposed view of firms' regular incremental and irregular non-incremental behavior. International Business Review, 23(1), 155-162.

Hadjikhani, A., Lee, J. W., \& Ghauri, P. (2001). Network view of MNCs' socio-political behavior. Journal of Business Research, 61(9), 912-924.

Hadjikhani, A., Lee, J. W., \& Park, S. (2016). Corporate social responsibility as a marketing strategy in foreign markets: The case of Korean MNCs in the Chinese electronics market. International Marketing Review, 33(4), 530-554.

Hadjikhani, A., \& Pahlberg, C. (2014). Multinational firms and political actors: The issue of corruption and transparency. International Journal of Business Environment, 6(2), 284-299.

Hofmann, E., Gangl, K., Kirchler, E., \& Stark, J. (2014). Enhancing tax compliance through coercive and legitimate power of tax authorities by concurrently diminishing or facilitating trust in tax authorities. Law \& Policy, 36(3), 290-313.

Howcroft, J. B., Ul-Haq, R., \& Hammerton, R. (2010). Bank regulation and the process of internationalisation: A study of Japanese bank entry into London. The Service Industries Journal, 30(8), 1359-1375.

Rjavalgi, R. G., \& Grossman, D. A. (2014). Firm resources and host-country factors impacting internationalization of knowledge-intensive service firms. Thunderbird International Business Review, 56(3), 285-300.

Katsikeas, C. S., \& Theodosiou, M. (2006). Strategy fit and performance consequences of international marketing standardization. Strategic Management Journal, 27(9), 867-890.

Keillor, B. D., \& Hult, T. M. (2004). Predictor of firm-level political behavior in the global business environment. International Business Review, 13(3), 309-329.

Khaaoubi, E. (2007). Crises, volatility and growth. The World Bank Economic Review, 2(3), 439-460.

Kizys, R., Paltalidis, N., \& Vergos, K. (2016). The quest for banking stability in the euro area: The role of government interventions. Journal of International Financial Markets, Institutions \& Money, 40, 111-133.

Laeven, L., \& Levine, R. (2009). Bank governance, regulation and risk taking. Journal of Financial Economics, 93(2), 259-275.

Litteljohn, D., Roper, A., \& Altinay, L. (2007). Territories still to find-The business of hotel internationalisation. International Journal of Service Industry Management, 18(2), 167-183.

Lovelock, C. H., \& Yip, G. S. (1996). Developing global strategies for service businesses. California Management Review, 38(2), 64-86.

Marquina, P., \& Morales, C. E. (2012). The influence of CSR on purchasing behaviour in Peru and Spain. International Marketing Review, 29(3), 299-312.

Mendoza, E. G., \& Smith, K. A. (2014). Financial globalization, financial crises, and the external portfolio structure of emerging markets. The Scandinavian Journal of Economics, 116(1), 20-57.

Mobus, J. L. (2005). Mandatory environmental disclosures in a legitimacy theory context. Accounting, Auditing and Accountability Journal, 18(4), 492-517.

Nederhand, M. J., Bekkers, V. J. J. M., \& Voorberg, W. H. (2016). Self-organization and the Role of Government: How and why does self-organization evelve inthe shadow of hierarchy? International Journal of Research and Thoery, 18(7), 1063-1084.

Nielsen, B. B., Asmussen, C. G., \& Weatherall, C. D. (2017). Location choice of foreign direct investments: Empirical evidence and challenges. Journal of World Business, 52, 62-82.

Nomden, K., Farnham, D., \& Onnee-Abbruciati, M.-L. (2003). Collective bargaining in public services: Some European comparisons. International Journal of Public Sector Management, 16(6), 412-423.

Oh, C. H., Park, J.-H., \& Ghauri, P. (2013). Doing right, investing right: socially responsible investing and shareholder activism in the financial sector. Business Horizons, 56(6), 703-714.

Okoye, A. (2009). Thoerizing CSR as an essentially contested concept. Journal of Business Ethics, $89(4), 613-624$. 
Pla-Barber, J., Villar, C., \& León-Darder, F. (2014). Augmenting versus exploiting entry modes in soft services reconsidering the role of experiential knowledge. International Marketing Review, 31(6), 621-636.

Polonsky, M., \& Jevons, C. (2009). Global branding and strategic CSR: An overview of three types of complexity. International Marketing Review, 26(3), 327-347.

Richardson, J. B. (1987). A sub-sectoral approach to services trade theory. In O. Giarini (Ed.), The emerging service economy (pp. 59-82). Oxford: Pergamon Press.

Rose-Ackerman, S. (1978). Corruption: A study in political economy. London: Academic Press.

Ross, A., \& Crossan, K. (2012). A review of the influence of corporate governance on the banking crises in the United Kingdom and Germany. Corporate Governance: The International Journal of Business in Society, 12(2), 215-225.

Samee, S. (1999). The internationalization of services, trends, obstacles and issues. Journal of Service Marketing, 13(4), 319-328.

Schwarz, N., \& Schuman, H. (1997). Political knowledge, attribution, and inferred interest in politics: the operation of buffer items. International Journal of Public Opinion Research, 9(2), 191-195.

Scott, W. R. (1995). Institutions and organizations. Thousand Oaks: Sage Publications.

Shirodkar, V., Beddewela, E., \& Richter, U. H. (2018). Firm-level determinants of political CSR in emerging economies: Evidence from India. Journal of Business Ethics, 48(3), 673-688.

Simonin, B. L. (1997). The importance of collaborative know-how: An empirical test of the learning organization. Academy of Management Journal, 40(5), 1150-1174.

Ting, H. (2017). Financial development, role of government, and bank profitability: Evidence from the 2008 financial crisis. Journal of Economics \& Finance, 41(2), 370-391.

Voss, H., Buckley, P., \& Cross, A. R. (2010). The impact of home country institutional effects on the internationalization strategy of Chinese firms. Multinational Business Review, 18(3), 25-48.

Wang, Y., \& Chaudhry, A. (2018). When and how managers' responses to online reviews affect subsequent reviews. Journal of Marketing Research, 55(2), 163-177.

Wickert, C. (2016). Political corporate social responsibility in small- and medium-sized enterprises. Business \& Society, 55(6), 792-824.

Yuliani, A., \& Ashly, H. (2017). The war for talent: Human capital challenges for professional service firms. Asia Pacific Business Review, 23(2), 205-229.

Zaefarian, R., Tasavori, M., \& Ghauri, P. N. (2015). A corporate social entrepreneurship approach to market-based poverty reduction. Emerging Markets Finance and Trade, 51(2), 320-334.

Zhou, Y., Chao, P., \& Huang, G. (2009). Modeling market orientation and Organizational antecedents in a social marketing context. International Marketing Review, 26(3), 256-274.

Publisher's Note Springer Nature remains neutral with regard to jurisdictional claims in published maps and institutional affiliations. 